\title{
As cartas privadas de John Wesley: uma abordagem da cena genérica e das produções do espaço associado de um autor como embreantes paratópicos
}

\author{
Manuel Veronez (UFO)* \\ https://orcid.org/0000-0002-8777-9859
}

\section{Resumo:}

Ao mobilizar o quadro teórico-metodológico da Análise do Discurso de linha francesa, sobretudo os trabalhos engendrados por Dominique Maingueneau, em especial o seu livro Discurso Literário (2012), consegui, em minha tese de doutorado, sustentar duas hipóteses: i) as cartas privadas de autores consagrados do campo literário funcionam enquanto um gênero do discurso (uma cena genérica) e não como um hipergênero; e ii) estas cartas privadas funcionam também como um embreante paratópico. A partir dos resultados alcançados, propus, enquanto projeto de pesquisa pós-doutoral, consolidar as cartas privadas de autores consagrados (enquanto uma cena genérica) dos discursos constituintes como um quarto embreante paratópico possível, incluindo-as ao grupo dos embreantes paratópicos proposto por Dominique Maingueneau: o ethos, a cenografia e o posicionamento na interlíngua. Desse modo, a hipótese central do meu projeto de Pós-doutorado é que as cartas privadas de autores consagrados (enquanto cena genérica e produção do espaço associado desses autores) dos discursos constituintes (o literário, o filosófico, o científico e o religioso) funcionam como um embreante paratópico. Nesta perspectiva, apresento, neste artigo, uma das análises propostas e realizadas em meu projeto pós-doutoral, onde analiso as cartas privadas de John Wesley, um autor consagrado do campo religioso.

Palavras-chave: Cartas privadas de autores consagrados. Cena genérica. Espaço associado de um autor. Embreagem paratópica. Discurso religioso.

\section{Résumé:}

\section{Les correspondances privées de John Wesley: une approche de la scène générique et de l'espace associé d'un auteur en tant que des embrayeurs paratopiques}

* Doutor em Estudos Linguísticos (bolsa CAPES) pela Universidade Federal de Uberlândia, com período sanduíche (bolsa CAPES/PDSE) na Université Paris-Sorbonne (Paris IV) sob a co-orientação do Prof. Dr. Dominique Maingueneau. Pós-doutorando em Linguística (bolsista CAPES/PNPD) na Universidade Federal de Uberlândia. E-mail: veronezmanuel@gmail.com 
À travers des travaux de Dominique Maingueneau dans Le discours littéraire - Paratopie et scène d'énonciation (2004) j'ai soutenu dans ma thèse de doctorat deux hypothèses: i) les correspondances privées des auteurs consacrés du discours littéraire fonctionnent en tant qu'un genre du discours (une scène générique) pas comme un hypergenre; et ii) ces correspondances privées, en tant qu'une scène générique et un espace associé des auteurs consacrés fonctionnent aussi comme un embrayeur paratopique. De cette façon, en continuant, dans mon projet de post-doctorat, je propose soutenir une nouvelle hypothèse, à suivre: la scène générique (surtout les correspondance privées des auteurs consacrés) des discours constituants fonctionne en tant qu'un embrayeur paratopique comme l'ethos, la scénographie et le positionnement dans l'interlangue abordés par Maingueneau (2012). Alors, dans cet article, pour vérifier ma nouvelle hypothèse, j'analyse donc les correspondances privées de John Wesley (un auteur consacré du discours religieux). Après, dans des autres travaux, j'analyserai les correspondances privées des auteurs consacrés des discours scientifique et philosophique pour renforcer l'hypothèse en parlé d'ailleurs.

Mots-clés: Correspondance privées des auteurs consacrés. Scène générique. Espace associé. Embrayage paratopique. Discours religieux.

\section{Introdução}

Mediante a mobilização do quadro teóricometodológico da Análise do Discurso de linha francesa, sobretudo os trabalhos de Dominique Maingueneau, consegui, em minha tese de doutorado, sustentar duas hipóteses: i) As cartas privadas de autores consagrados do campo literário funcionam como um gênero do discurso, não como um hipergênero; e ii) Essas cartas privadas, enquanto uma cena genérica (que designa o gênero do discurso), funcionam também como um embreante paratópico. Na tese (2018), para buscar sustentar essas hipóteses, objetivei analisar o funcionamento da autoria, a constituição da paratopia e as cenografias construídas nas cartas privadas trocadas entre Mário de Andrade e Carlos Drummond de Andrade.

Buscando, assim, desdobrar minha tese de doutorado, especificamente em relação aos seus resultados, propus, enquanto pro- jeto de pesquisa de pós-doutorado, apresentar e consolidar as cartas privadas de autores consagrados (enquanto cena genérica e produção do espaço associado desses autores) dos discursos constituintes propostos por Maingueneau (o literário, o filosófico, o científico e o religioso) como um quarto embreante paratópico possível, incluindo, assim, tais cartas privadas ao grupo dos embreantes paratópicos alvitrado por Dominique Maingueneau, a saber: o ethos, a cenografia e o posicionamento na interlíngua.

Desse modo, a hipótese central do meu projeto de Pós-doutorado é que as cartas privadas de autores consagrados dos discursos constituintes, que funcionam como uma cena genérica e produção do espaço associado desses autores, também funcionam como um embreante paratópico.

Para buscar sustentar tal hipótese, selecionei, enquanto corpus de análise da minha 
pesquisa pós-doutoral, cartas privadas de autores consagrados dos campos Filosófico, Científico e Religioso (não tratei do campo Literário no projeto de Pós-doutorado, porque ele já foi trabalhado em minha tese de doutorado de forma mais densa) e percorri três objetivos específicos (por uma questão de produtividade e regularidade, mantive os mesmos objetivos propostos em minha tese), a se ver: i) Analisar como se dá o imbricamento entre as três instâncias constitutivas do funcionamento da autoria (a pessoa; o escritor; e o inscritor) nas cartas privadas de Sêneca, Freud e John Wesley; ii) Analisar como se dá a constituição da paratopia nessas mesmas cartas privadas desses mesmos autores consagrados; e iii) analisar a emergência e a construção das cenografias que são encenadas nos e pelos textos dessas mesmas cartas privadas, desses mesmos autores consagrados.

No artigo em questão, para mostrar a regularidade e a pertinência de se sustentar a hipótese central do meu projeto de Pósdoutorado, apresentarei as análises realizadas das cartas privadas de John Wesley, um autor consagrado do campo religioso inglês do século XVIII.

\section{Constituição do corpus}

O corpus de análise do meu projeto de Pósdoutorado constitui-se de cartas privadas de autores consagrados dos campos discursivos filosófico, científico e religioso, cujos discursos, segundo Maingueneau (2012), são chamados de constituintes.

Assim sendo, para o discurso filosófico, selecionei as cartas privadas de Sêneca; e para o discurso científico, selecionei as cartas privadas de Freud. No artigo aqui apresentado, para o discurso religioso, mostro análise feita nas cartas privadas de John Wesley.
Vale ressaltar que para o discurso literário eu analisei, em minha tese de doutorado, as cartas privadas trocadas entre Mário de Andrade e Carlos Drummond de Andrade. Além da tese, eu também publiquei artigo (2019) em que apresento de forma concisa os resultados alcançados.

\section{Arcabouço teórico}

Nesta seção, apresento o quadro teóricometodológico que sustentará a análise das cartas privadas de John Wesley. Desse modo, é importante apresentar as noções de discurso constituinte, funcionamento da autoria, produção do espaço associado de um autor, paratopia, gênero do discurso (cena genérica) e cenografia, conforme abordado por Dominique Maingueneau (2012).

Os discursos constituintes são discursos que apresentam uma natureza especial de funcionamento em relação aos outros discursos denominados não constituintes. Os discursos constituintes pretendem negar a interdiscursividade (cf. Maingueneau, 2008a), alegando não se inter-relacionarem com outros discursos. Para o autor, os discursos constituintes se consideram discursos fontes, de Origem, em que são validados por uma cena de enunciação (cf. Maingueneau, 2008a) que autoriza a si mesma. Os discursos constituintes têm a pretensão de afirmar que estão em contato direto com as fontes que os legitimam, não necessitando assim, da inter-relação interdiscursiva, ou seja, o discurso literário está diretamente ligado à musa, o discurso filosófico à razão, o discurso científico ao método e o discurso religioso à Deus.

Os processos de subjetivação que atuam na criação literária são tão complexos que, segundo Maingueneau (2012), não se pode reduzi-los a uma simples oposição entre escritor (alguém dotado de um estado civil) e 
enunciador (correlato de um texto). As teorias tradicionais que trabalham com essa tópica são insuficientes e inoperantes, pois elas não levam em consideração o caráter constitutivo da instituição literária e, desse modo, não conseguem avaliar seu aspecto sistêmico, dinâmico, instável e paradoxal. De acordo com o autor, a palavra "escritor" (écrivain) é problemática, pois pode designar, ao mesmo tempo, uma profissão, a do escrivão, e/ou uma figura associada a uma obra. A palavra "autor", por sua vez, já referenciaria uma condição social ou alguém que seria a fonte e o garante da obra. Entretanto, a noção de "enunciador" não é de uso comum, ela é um conceito linguístico recente e seu valor permanece ainda instável, podendo ser uma instância interior ao enunciado ou um simples locutor, aquele que produz o discurso.

Dessa maneira, Maingueneau (2012) propõe uma abordagem diferente, o que ele denomina de funcionamento da autoria. Segundo o autor, o dispositivo institucional, os conteúdos manifestos e a relação interlocutiva que se mobilizam no interior do campo discursivo literário se entrelaçam e se sustentam mutuamente, legitimando e constituindo a cena de enunciação que os delimita. Qualquer que seja as formas de subjetivação do discurso literário, não se pode conceber sujeito biográfico e sujeito enunciador como duas entidades sem comunicação. Assim, o autor propõe distinguir três instâncias, ao invés de duas, a se ver: a instância da pessoa, a instância do escritor e a instância do inscritor:

A denominação "a pessoa" refere-se ao indivíduo dotado de um estado civil, de uma vida privada. "O escritor" designa o ator que define uma trajetória na instituição literária. Quanto ao neologismo "inscritor", ele subsume ao mesmo tempo as formas de subjetividade enunciativa da cena de fala implicada pelo texto (aquilo que vamos chamar adiante de "cenografia") e a cena imposta pelo gênero do discurso: romancista, dramaturgo, contista... 0 "inscritor" é, com efeito, tanto enunciador de um texto específico como, queira ou não, o ministro da instituição literária, que confere sentido aos contratos implicados pelas cenas genéricas e que delas se faz o garante. (MAINGUENEAU, 2012, p. 136)

Essas instâncias não se apresentam em sequência, não há, em primeiro lugar, a pessoa, em segundo, o escritor e em terceiro, o inscritor. Segundo Maingueneau (2012), essas instâncias são atravessadas umas pelas outras e cada uma delas sustenta as outras duas e vice-versa, em um processo recíproco que dispersa e concentra o criador. As três instâncias constitutivas do funcionamento da autoria não se isolam, pois é na inter-relação que elas dão condição ao desencadeamento do processo de criação. Em outras palavras, rompendo-se com uma das três instâncias, as duas outras sucumbemse, uma vez que é através do inscritor que a pessoa e o escritor enunciam; é através da pessoa que o inscritor e o escritor vivem; e é através do escritor que a pessoa e o inscritor traçam uma trajetória no espaço literário.

Com objetivo de ampliar a distinção entre regime delocutivo e regime elocutivo e, dessa forma, negar a ideia dicotômica entre texto literário e texto não literário, Maingueneau (2012) afirma que as produções de todo autor se vinculam a dois espaços indissociáveis, mas que não estão no mesmo plano: o espaço canônico e o espaço associado. O espaço associado não pode ser concebido como equivalente à ideia de "paratexto" desenvolvida por Genette (1987), mas está mais vinculado ao regime elocutivo, cujas obras produzidas buscam comentar e interpretar as obras ditas "canônicas”, denominadas, por Maingueneau (2012), de espaço 
canônico de um autor, para legitimá-las e constituí-las no interior do campo literário. 0 espaço associado de um autor pode ser composto, por exemplo, pelas suas cartas privadas trocadas com destinatários, pelos prefácios, pelos artigos publicados em jornais e revistas, pelas suas entrevistas etc.

A paratopia, de acordo com Dominique Maingueneau (2012), constitui e legitima a literatura (como um todo) e o autor (criador). Todo escritor só se torna, de fato, um criador, ao assumir sua condição paratópica. A paratopia, assim, está diretamente relacionada ao processo criador. 0 escritor não tem lugar determinado para se estabelecer, mas precisa negociar incessantemente um lugar de adesão, sempre difícil, uma vez que ele se constitui através da sua impossibilidade de obter uma topia, isto é, um lugar institucionalizado. Nessa perspectiva, sua negociação entre o lugar e o não lugar é sempre ímprobo, o que dá condições de criação ao criador. A paratopia do autor, segundo Maingueneau (2012), está relacionada ao espaço literário e à sociedade onde ele busca uma inscrição. Todo escritor tem um modo singular de gerir seu posicionamento no interior do campo literário. A paratopia, para o autor francês, é um pertencimento paradoxal. Ela não é nem condição inicial nem condição final, mas o processo, pois só existe paratopia ao se mobilizar atividade criadora e enunciação:

Nem suporte nem quadro, a paratopia envolve o processo criador, que também a envolve: fazer uma obra é, num só movimento, produzi-la e construir por esse mesmo ato as condições que permitem produzir essa obra. Logo, não há "situação" paratópica exterior a um processo de criação: dada e elaborada, estruturante e estruturada, a paratopia é simultaneamente aquilo de que se precisa ficar livre por meio da criação e aquilo que a criação aprofunda; é a um só tempo aquilo que cria a possibilidade de acesso a um lugar e aquilo que proíbe todo o pertencimento. (MAINGUENEAU, 2012, p. 109)

É importante ressaltar que a paratopia é do autor, mas ela só é criadora quando relacionada à figura do insustentável. A enunciação literária é justamente a negociação desse insustentável, dessa impossível tentativa de inscrição do autor na sociedade e no espaço literário que o circunscrevem. 0 escritor precisa escrever (criar) para legitimar sua situação paratópica, pois ele se encontra dentro e fora desse mundo. É no processo de criação que o escritor precisa apresentar sua condição insustentável, seu jogo de pertencimento e não pertencimento em uma topia (como expresso alhures). Maingueneau (2012) afirma que o escritor preserva sua paratopia escrevendo, ou seja, produzindo. Desse modo, a paratopia criadora do autor é, ao mesmo tempo, a condição e o produto de uma criação.

Maingueneau (2012) afirma que a relação entre texto e contexto se funda num dado constitutivo da enunciação literária. Em outras palavras, a obra precisa apresentar, no próprio mundo que constrói, suas condições de enunciação e seu caráter insustentável, ou seja, paratópico. Pode-se falar, nesta perspectiva, "de uma espécie de embreagem do texto sobre suas condições de enunciação e, em primeiro lugar, sobre a paratopia que é seu motor" (p. 121), podese falar, assim, ainda de acordo com o autor, em uma embreagem paratópica.

0 termo embreagem, que Maingueneau (2012) recupera da linguística, especificamente da semiótica (cf. Greimas e Courtés, 1979), implica a consideração de um ou mais elementos linguísticos que inscreveriam no enunciado suas relações com a situação de enunciação. São, assim, denominados embreantes os elementos que par- 
ticipam, ao mesmo tempo, da língua e do mundo, ou seja, são signos linguísticos que adquirem determinado valor por meio do evento enunciativo que os produz. Desse modo, a partir dessa noção de embreagem linguística/semiótica, Maingueneau (2012) apresenta seu conceito de embreagem paratópica, que são elementos de variadas ordens que participariam, ao mesmo tempo, do mundo criado pela obra e da situação paratópica do autor, que é condição e produto da criação literária.

A noção de gênero do discurso, de acordo com Maingueneau (2015), é definida como um dispositivo comunicacional social e historicamente definido. Essa noção é concebida por meio das metáforas de "contrato", de "ritual" ou de "jogo". Tal noção opera por meio de cenas de enunciação, em que ela também é chamada de cena genérica, uma espécie de instituição de fala. Para o autor, a cena de enunciação é composta pela cena englobante (tipo de discurso), pela cena genérica (gênero do discurso) e pela cenografia. Desse modo, os gêneros do discurso apenas ganham sentido quando imbricados com os tipos de discurso e com a cenografia.

Os tipos de discurso correspondem, basicamente, a um setor da atividade social, a uma rede de gêneros do discurso que se imbricam, se relacionam e constituem um discurso, como o discurso literário, o discurso religioso, o discurso científico, o discurso filosófico, o discurso político, o discurso publicitário etc. Todo gênero do discurso é proveniente de um tipo de discurso e todo tipo de discurso é constituído de gêneros do discurso.

A cenografia, por sua vez, é definida por Maingueneau (2012) como sendo a cena de fala construída no e pelo texto. A cenografia não é uma simples decoração, ou seja, não se trata somente de uma questão de estilís- tica linguística, a cenografia é um aspecto legitimador da enunciação e da construção do texto, assim como, paradoxalmente, a própria cenografia é também legitimada por essa mesma enunciação: o enunciador instaura, através de sua enunciação, a situação, o mundo a partir do qual ele pretende "mostrar-se" e, ao mesmo tempo, legitimar sua enunciação. A cenografia se apoia, especificamente, nesse tipo de funcionamento.

Desse modo, para o autor, uma cenografia só se desenvolve plenamente se o locutor puder controlar seu desenvolvimento. Em um enunciado monológico, por exemplo, Maingueneau (2015) afirma que o locutor tem domínio de todo o processo enunciativo, o que dá a possibilidade de construção de cenografias mais ou menos estáveis, “duras" (rígidas) e controladas, o que não acontece nos diálogos, em uma interação oral, por exemplo, em que os locutores (participantes) não conseguem impor, manter, nem controlar uma mesma cenografia ao longo de todo o processo de interação oral no qual estão envolvidos. Isso se dá devido às situações enunciativas imprevisíveis às quais os interlocutores precisam reagir instantaneamente e espontaneamente, no caso da interação oral.

No capítulo "Cenografia epistolar e debate público", Maingueneau (2008b) afirma que a cenografia é um tipo de "armadilha" para o leitor, pois, se a cenografia for bem explorada, o leitor receberá o texto como sendo o texto encenado pela cenografia e não como o texto previsto pela cena genérica em si. Nesse sentido, a escolha da cenografia não é alheia nem indiferente, pois o discurso, posicionando-se a partir de sua cenografia, pretende convencer instituindo a cena de enunciação que o legitima. Segundo o autor, o discurso impõe sua cenografia desde o início, mas, ao mesmo tempo, é 
através de sua própria enunciação que ele poderá legitimar essa mesma cenografia. Segundo o autor:

Uma cenografia é identificada com base em variados índices localizáveis no texto ou no paratexto, mas não se espera que ela designe a si mesma; a cenografia se mostra, por definição, para além de toda cena de fala que seja dita no texto. A noção de "cenografia" adiciona ao caráter teatral de "cena" a dimensão da grafia. Essa "-grafia" não remete a uma oposição empírica entre suporte oral e suporte gráfico, mas a um processo fundador, à inscrição legitimadora de um texto, em sua dupla relação com a memória de uma enunciação que se situa na filiação de outras enunciações e que reivindica um certo tipo de reemprego. (MAINGUENEAU, 2012, p. 252-253, grifos do autor)

\section{Análise das cartas privadas de John Wesley}

Nessa seção, apresento a análise das cartas privadas de John Wesley. Ao mobilizar os três objetivos propostos em meu projeto de Pós-doutorado (funcionamento da autoria, constituição da paratopia e as cenografias), busco sustentar minha hipótese central, qual seja: as cartas privadas de autores consagrados (enquanto uma cena genérica e uma produção do espaço associado desses autores) dos discursos constituintes funcionam como embreantes paratópicos.

Após a reforma calvinista, surgiram, na Europa, variadas correntes cristãs que buscavam estudar e pregar o cristianismo de uma maneira diferente daquela, até então, imposta pelo catolicismo, que era o posicionamento discursivo dominante da época. John Wesley, ainda um clérigo anglicano e teólogo cristão britânico, se tornou, tempos depois, líder precursor do movimento metodista - uma sociedade religiosa cristã que buscava instituir, no interior do campo religioso inglês do século XVIII um posicionamento cristão diferente do da Igreja Católica, bem como do da Igreja da Inglaterra (ou Igreja Anglicana) e dos Morávios. John Wesley, assim, vindo inicialmente da Igreja Anglicana, se torna, posteriormente, um reformador, já que inicia uma obra de regeneração, e o principal líder e autor do movimento metodista.

Segundo Potts (1991), foi ainda na Universidade de Oxford, quando estudante, que o nome "metodista" surgiu para John Wesley, ao se tornar líder do grupo denominado "Holy Club", uma sociedade pertencente à Igreja da Inglaterra, que seguia métodos bastante rigorosos para uma vida santificada. O nome "metodista" surgiu como "zombaria" (p. 4) criada por outros membros da Igreja Anglicana, que buscavam desmerecer o clube de John Wesley devido à rigidez de seu método.

De acordo com o autor, foi após uma reunião com a sociedade anglicana em 24 de maio de 1738, em Londres, depois de ter retornado da Georgia (então colônia da Inglaterra) em missão evangelizadora, que John Wesley resolve deixar a sociedade, pois teve alguns problemas com ela. Foi, assim, a partir dessa data e durante 53 anos de trabalho evangelizador (orando, pregando, escrevendo etc.), que John Wesley liderou o "movimento que veio a se tornar a Igreja Metodista" (POTTS, 1991, p. 5).

Para o historiador Rattembury (1928), John Wesley modificou o curso da história inglesa, o que corrobora na ideia de que ele é um autor consagrado do campo religioso inglês do século XVIII, passível de ter suas produções, como suas cartas privadas, por exemplo, estudadas e analisadas. 0 autor afirma o seguinte:

Há na verdade, pouca dúvida, de que o cidadão inglês do século dezoito, de maior im- 
portância para o mundo não era um político nem poeta, nem soldado ou marinheiro, mas o pequeno itinerante a cavalo - o Grande Cavaleiro, como eu o chamaria - que ainda está cavalgando para novas conquistas. (RATTEMBURY, 1928, p. 53)

Faz-se mister ressaltar que, para a análise do funcionamento da autoria, as três instâncias constitutivas do seu funcionamento (a pessoa, o escritor e o inscritor) não se dão de forma estanque nos enunciados das cartas privadas, em que poderiam ser percebidas apenas em excertos específicos. Nesta perspectiva, essas três instâncias são constitutivas da enunciação que dá condições à produção da prática de trocas de cartas privadas engendradas por John Wesley, atravessando, assim, todos os enunciados produzidos. Porém, para a análise a seguir, como forma de apresentação desse funcionamento da autoria, serão escolhidos trechos das cartas privadas que evidenciam com mais clareza tal funcionamento.

Desse modo, em relação ao funcionamento da instância da pessoa, denominado por Maingueneau (2012) como sendo os dados biográficos e as questões íntimas do autor que atravessam na enunciação, John Wesley, em uma carta privada para sua mãe, de 23 de setembro de 1723, enuncia sobre sua vida na cidade de Oxford e na Universidade de Oxford, como questões de aluguel, os problemas da varíola e da febre que se alastravam na cidade, de um problema em seu nariz, dentre outras questões de cunho pessoal. Eis um excerto desta carta privada:

Eu ouvi ultimamente de meu irmão, que, então, prometeu-me que pediria ao Sr. Sherman para me deixar o aluguel de seu quarto, e alocação do trimestre, pelo que, juntamente com 5 libras e 11 cents, da Charterhouse no Michaelmas Day, eu espero estar muito próximo de não dever mais em lugar algum. A varíola e febre são agora muito comuns em Oxford; da segunda, um jovem cavalheiro, muito sincero de nosso Colégio, morreu ontem, estando no quinto dia do início de sua enfermidade. Não existe algum outro doente na Universidade no momento, e é esperado que a aproximação do inverno irá parar a propagação da doença. Estou muito feliz em saber que todos em casa estão bem; como estou, eu agradeço a Deus, no momento, sendo raramente incomodado com nada, a não ser o sangramento no nariz, o que eu tenho com frequência. Há pouco tempo, ele sangrou tão violentamente quando eu estava andando à noite uma ou duas milhas de Oxford, que quase me engasguei; nem qualquer método que eu poderia usar, afinal, o diminuiu, até que eu me despi e saltei no rio, que felizmente não estava longe. (WESLEY, 2018, n.p.)

John Wesley também enuncia em suas cartas privadas seu cotidiano de pregações e evangelizações. A seguir, temos alguns excertos da carta privada de 16 de março de 1739 escrita por John Wesley para seu amigo Whitefield (também um evangelizador), onde o autor da carta fala das suas ocupações diárias. Observa-se, nesses excertos, por exemplo, a instância da pessoa interligada fortemente à instância do escritor, pois ao apresentar seu dia a dia a Whitefield, Wesley apresenta também seu trabalho enquanto evangelizador e pregador, legitimando seu posicionamento metodista, daquele que trabalha incessantemente fora das paróquias e das igrejas em nome de Deus, por meio apenas da Fé e das Sagradas escrituras:

Na terça-feira, dia 8 do corrente, nós tomamos o desjejum na casa do Sr. Score, Oxford, que está pacientemente esperando pela salvação da parte de Deus. De lá, fomos até a Sra. Campton, que tem um coração de pedra, e reconhece que ela não deve estar envergonhada. (...). Das cinco às seis horas, nós estávamos confirmando os irmãos. Às seis horas, eu expus na casa da sra. Ford; como eu pretendia fazer na casa da sra. Compton, 
às sete. (...); e o resultado disto foi que, em vez de partir de Londres (como eu designara) na sexta-feira de manhã, eu partiria para Dummer, não havendo pessoa alguma para suprir aquela igreja no domingo. Na sextafeira, portanto, eu parti, e vim, à noite para Reading, onde eu encontrei um jovem, Cennick, de nome, forte na fé de nosso Senhor Jesus. (...). Nós viemos para Dummer, à tarde. (...). No domingo de manhã, nós tivemos uma larga e atenta congregação. À noite, a sala em Basingstoke estava cheia e minha boca estava aberta. (...). Na segunda-feira, a sra. Cleminger, com dor e medo, nós oramos e nosso Senhor trouxe paz. Por volta do meiodia, passamos uma hora ou duas em conferência e oração com a srta. Molly; e, então, partimos em uma gloriosa tempestade, mas, até mesmo eu, tive calma nela. (WESLEY, 2005, p. 173-175)

0 autor inglês também enuncia, por exemplo, sua aflição para com sua mãe, se queixando de um certo amor maternal pouco deliberado por ela por razões que ele julga injustas. Eis o excerto dessa carta privada de 28 de fevereiro de 1732 :

Querida mãe, há apenas um motivo de preocupação que às vezes encontro em seu comportamento para comigo. A senhora realiza os mais nobres préstimos de amor por mim, e, entretanto, culpa a Fonte de onde eles fluem. A senhora disse mais de uma vez que me ama demais e que lutaria para me amar menos. É disso que eu me queixo. A senhora não acha que uma afeição natural é má em si mesma, longe disso. Mas diz que tem apenas um pouco mais de tempo no mundo e, portanto, não deveria ter muito apego por qualquer coisa dele. Muito certo: não por qualquer coisa que pereça com o mundo. Mas eu sou uma dessas coisas? Se a senhora pensa que estou "doente para morrer", ame-me mais e a senhora orará com mais fervor para que eu seja curado. (WESLEY, 1991, p. 36)

Atrelada à instância da pessoa está a instância do escritor que, segundo Maingueneau
(2012), designa um ator que define uma trajetória na instituição literária. John Wesley busca legitimar e constituir o posicionamento metodista no interior do campo religioso inglês do século XVIII. Segundo sua doutrina metodista, apenas a Fé e as Sagradas Escrituras são verdadeiramente suficientes para se compreender e chegar a Deus, para congregá-lo, aceitá-lo e amá-lo incondicionalmente, sem a necessidade de mediadores, como os santos e as imagens mobilizadas pela Igreja Católica, por exemplo. 0 metodismo também buscava se diferenciar dos outros posicionamentos cristãos que surgiram após a reforma protestante, como a Igreja Anglicana e os Morávios. Dessa maneira, outro ponto forte da prática social e discursiva dos metodistas é o engajamento em questões de assistência e ação social.

Nesta perspectiva, John Wesley defende em uma carta privada a um membro da Igreja Metodista, Samuel, em 30 de outubro de 1738, o que era ser um verdadeiro cristão segundo sua doutrina, diferentemente da ideia difundida pelos católicos, anglicanos, protestantes e morávios. Para o autor inglês, ser cristão é ter fé em Cristo por meio da graça de Deus e nada mais. Observa-se, assim, que é por meio da prática discursiva da troca de cartas privadas que Wesley consegue apresentar e discutir sua doutrina. Com tal prática, Wesley consegue legitimar e constituir seu posicionamento, pois ao enunciar sua doutrina em cartas, ele pretende, por meio do processo de enunciação e de produção delas, se mostrar enquanto um evangelizador legítimo e além, se mostrar como alguém que engendra pregações autorizadas no interior da comunidade religiosa em que busca sua inscrição. Eis o excerto desta carta privada:

A respeito de meu próprio caráter, e também de minha doutrina, eu responderei com mui- 
ta franqueza. 0 cristão, como eu o entendo, é aquele que crê em Cristo tão intensamente que o pecado não tem mais domínio sobre ele; e é nesse sentido claro da palavra que eu não era um cristão até o dia 24 de maio do ano passado. (...); mas, com certeza, daquele momento até agora isso não mais acontece - tal é a graça ilimitada de Deus em Cristo. (...). Se você me perguntar de que modo me libertei (embora não perfeito, nem infalivelmente seguro de minha perseverança), eu responderei, "Pela fé em Cristo; por uma fé de tal qualidade e grau como jamais senti até aquele dia”. (WESLEY, 1991, p. 7-8)

Em outras duas cartas privadas, por exemplo, de 28 de dezembro de 1770 e de 27 de janeiro de 1767, John Wesley, respectivamente, para Joseph Benson e para seu irmão Charles Wesley, também defende outras duas coisas: i) é somente através da fé em Cristo a única forma de se justificar cristão; e ii) é possível chegar a uma perfeição cristã segundo os princípios metodistas, através da reflexão sobre o assunto, o modo e o tempo, reforçando e legitimando, assim, uma vez mais, seu posicionamento discursivo. Os trechos destas duas cartas privadas são o seguinte:

Pode alguém ser justificado a não ser pela fé? Ninguém pode. Portanto você é um crente; você tem fé em Cristo; conhece o Senhor e pode dizer, "Meu Senhor e meu Deus". E quem negar isto pode também negar que o sol brilha ao meio-dia. (...). Eu estava pensando na Perfeição Cristã, considerando o assunto, o modo e o tempo. 1. Por perfeição eu quero dizer o humilde, gentil, paciente amor de Deus e do homem governando todos os temperamentos, palavras e ações, todo o coração por toda a vida. (...). 2. A respeito do modo. Creio que esta perfeição é formada na alma pela fé, por um simples ato de fé, consequentemente em um instante. Mas, creio em um trabalho gradual tanto precedendo como seguindo esse instante. (...). 3. A respeito do tempo. Creio que este instante é ge- ralmente o momento da morte, o momento antes da alma deixar o corpo. Mas, creio que possa ser dez, vinte, ou quarenta anos antes da morte. (WESLEY, 1991, p. 8, 31 e 32)

John Wesley, defendendo frente a James Hervey seu posicionamento metodista, em sua carta privada de 20 de março de 1739 , afirma também que, para um metodista, não há necessidade de um lugar específico para as pregações e as evangelizações, como igrejas, púlpitos, paróquias etc., pois o metodista verdadeiro prega e evangeliza em qualquer lugar - seja no campo, em minas de carvão, do lado de fora das igrejas etc. Essa questão de levar a palavra de Deus por meio das Sagradas Escrituras para qualquer ambiente, no entanto, também se dá pelo fato de que os líderes da Igreja Anglicana, onde Wesley se formou, começaram a negar e a proibir as pregações e evangelizações de Wesley, bem como de outros membros da sociedade metodista, em suas igrejas, paróquias e púlpitos. No excerto desta carta privada, a seguir, o autor inglês enuncia o seguinte:

Permita-me agora falar a respeito dos meus princípios concernentes a este assunto. $\mathrm{Eu}$ vejo todo o mundo como minha paróquia; desse modo eu acho, que em qualquer parte dele em que eu estiver, julgo correto, próprio e meu sagrado dever proclamar, para todo os que quiserem ouvir, as alegres novas da salvação. (...); e, como tal, sou usado de acordo com a clara direção de Sua palavra: "quando tiver oportunidade, fazer o bem a todos os homens". E Sua providência concorda claramente com Sua palavra, que tem me livrado de todas as outras coisas para que possa simplesmente fazer só isso, andar "por toda a parte fazendo o bem". (WESLEY, 1991, p. 9-10)

Em outras cartas privadas, John Wesley, buscando legitimar e constituir seu posicionamento metodista no interior da instituição religiosa da Inglaterra do século XVIII, 
enuncia a Sra. March, em 29 de março de 1760 e 29 de junho de 1767, duas coisas: i) a única forma de comunicação direta com Deus é através da oração, sem uma necessidade de mediadores, como os anjos, os santos, as imagens etc., cujas práticas eram mobilizadas pelo posicionamento católico ainda dominante na época, como já dito anteriormente; e ii) o único caminho para a salvação e o bem viver é Deus, nada mais além disso. Wesley busca se legitimar e se constituir enquanto autor/evangelizador da instituição religiosa onde pretende ter sua inscrição (sempre difícil), percorrendo-a, dentre outras maneiras, através da prática da troca de cartas privadas, que, ao legitimar seu estatuto de autor/evangelizador, tal estatuto também o legitima a produzir e a apresentar sua doutrina por meio da enunciação das cartas. Eis os excertos destas duas cartas privadas:

A oração é certamente o grande meio de nos achegarmos mais perto de Deus; todos os outros são úteis a nós desde que sejam usados juntos ou nos preparem para isso. (...). Você resolveu ser uma cristã seguidora da Bíblia; e isso, pela graça de Deus, não em alguns, mas em todos os pontos. Continue no nome de Deus e na força de Seu poder. Todavia ponha seus olhos em uma só coisa; fixe num só ponto; retenha e aumente sua comunhão com Deus! Você não tem nada mais a fazer. (WESLEY, 1991, p. 11, 12 e 13)

Na carta privada de 25 de junho de 1771, John Wesley, seguindo a doutrina metodista legitimadora do seu posicionamento discursivo, busca auxiliar a Sra. March, apresentando-a aos ensinamentos dos vários graus de comunhão com Deus. Suas cartas, enquanto uma produção do seu espaço associado, buscam também legitimar suas produções do espaço canônico, comentando-as de uma certa maneira, como os sermões que produziu. Seu espaço associado legitima e constitui, assim, seu posicionamento e seu estatuto de autor, evangelizador e produtor de obras, pois é por meio da prática discursiva da troca de cartas privadas e das condições sociais e históricas de produção que legitimam sua enunciação, que Wesley consegue expor e comentar sua doutrina metodista. Na carta diz:

Indubitavelmente há vários tipos e vários graus de comunhão com Deus. Não podemos nos limitar a apenas um; pode incluir o exercício de todas as emoções, ou separadamente ou em várias combinações; e pode percorrer todos os nossos afazeres externos. A oração mais desejável é aquela que nos leva a abrir nossa alma e falar livremente com Deus. Mas não apenas isto é aceitável a Ele. (...). Tenha cuidado para não pensar que este é um trabalho perdido. Deus opera muito nos corações mesmo nessas ocasiões. (WESLEY, 1991, p. 13)

Da mesma forma, atrelada também às duas outras instâncias, observamos a emergência da instância do inscritor. Esta instância, de acordo com Maingueneau (2012), implica uma relação subjetiva do escritor com o gênero do discurso que ele mobiliza e a cenografia construída no/pelo texto. Dessa maneira, John Wesley se vale, em suas cartas privadas, de aconselhamentos e orientações aos seus fiéis da comunidade metodista como uma forma de posicionarse em relação às instâncias do gênero e do texto, assumindo ser a recomendação de atitudes e a proposição de caminhos para se chegar até Deus, sempre num tom imperativo, adequadas ao gênero/texto por meio do qual enuncia, o que garante a legitimação do seu estatuto de autor e evangelizador, pois ele busca, com a mobilização dos conselhos e orientações, a partir do seu posicionamento, se afirmar como um exímio pregador do campo religioso.

A seguir, apresento excertos de algumas cartas privadas do autor mostrando, nelas, a 
regularidade da apresentação desses conselhos, orientações, recomendações e trilhagem de caminhos. Os excertos destas cartas privadas, a seguir, são, respectivamente, de 28 de dezembro de 1770 , de 17 de maio de 1766, de março de 1773, de 29 de março de 1760 , de 29 de junho de 1767 e de $1^{\circ}$ de julho de 1789:

Num ponto eu recomendo que você seja firme e não permita que nem homens ou demônios o arranquem de sua vida. (...). Seus pecados estão perdoados! Não lance fora essa segurança que tem grande recompensa de galardão. (...). Alimente-a com todas as suas forças! Reavive continuamente o dom de Deus que tem em si, não apenas ouvindo constantemente a Sua palavra em todas as oportunidades, mas também lendo, meditando e, acima de tudo, orando em particular. Embora às vezes isso possa parecer uma cruz penosa, assim mesmo leve sua cruz, e ela a levará; (...). Eu quero que a senhora seja semelhante a Ele em tudo. (...). Querido George - Chegou a hora de você embarcar para a América. Você deve ir até Bristol, onde se encontrará com Thomas Rankin, o Capitão Webb e sua esposa. (...). Proclame abertamente a sua mensagem e faça todo o bem que puder. (...). Lembre-se do seu chamado; seja Uma simples seguidora do Cordeiro, e inofensiva como uma criancinha. (...). Não, fique firme, andando em todas as situações como Cristo também andou. (...). Continue no nome de Deus e na força de Seu poder. (...). E permita-me dar-lhe mais um conselho (antigamente você dava valor aos meus conselhos) - deixe de lado as disputas. Tire seus pensamentos, tanto quanto possível, de todos os pontos controversos. Você só deve prestar atenção a um ponto - Emanuel, Deus conosco; deve se fixar em um único ponto Cristo em nós, a esperança da glória! (WESLEY, 1991, p. 8, 9, 10, 12, 25 e 26)

Em relação à constituição da paratopia de John Wesley (a impossível negociação entre o lugar e o não lugar), que também está atrelada às três instâncias constitutivas do funcionamento da autoria, o autor, por meio da prática discursiva da troca de cartas privadas, busca legitimar e constituir seu posicionamento metodista, ou seja, legitimar e constituir sua religião no interior do campo religioso inglês do século XVIII. No entanto, a negociação é sempre difícil, impossível, entre o espaço religioso e a sociedade que o circunscrevem. John Wesley não se encontrava dentro da fé cristã no interior da Igreja Anglicana (sua formação inicial), muito menos no interior da Igreja Católica ou entre os Morávios, estes lugares não eram o seu lugar: eis sua paratopia. De acordo com Potts (1991, p. 4), John Wesley "falou sobre essa experiência na qual, ao ir para a Georgia a fim de converter os índios, descobriu que ele próprio jamais havia se convertido".

Além disso, a constituição da sua paratopia se dá também pela oposição que sofria ainda na Igreja Anglicana, em que haviam oponentes, caluniadores e perturbadores que buscavam sua expulsão no interior de tal comunidade discursiva. John Wesley foi proibido de pregar e evangelizar nas paróquias e púlpitos da Igreja Anglicana e da sociedade dos Morávios. John Wesley era considerado dissidente (um sem lugar, um paratópico), devido ao seu posicionamento cristão, que se diferenciava do posicionamento dos líderes da Igreja da Inglaterra, por exemplo. Daí sua necessidade de criar uma nova Igreja, a Igreja Metodista.

Desse modo, o processo de enunciação das cartas privadas de John Wesley se legitima e se constitui pela sua paratopia, pelo caráter insustentável, insuficiente do autor, pois, na negociação entre a sociedade e o espaço religioso em que busca sua inscrição, ele é acometido por conflitos, oposições, incompreensões, brigas, embates e disputas com outros pregadores e evangelistas, 
sejam os calvinistas ou até mesmo membros de sua própria comunidade. Eis, como exemplo, o excerto de uma carta privada de John Wesley, de 16 de março de 1739, para Whitefield, em que ele apresenta o funcionamento e a emergência da constituição da sua paratopia:

Depois de passarmos algum tempo em oração, o sr. Washington veio com o sr. Gibb, e leu diversas passagens do livro do Bispo Patrick, Parábola do Peregrino, para provar que nós estávamos todos, sob ilusão, e que seríamos justificados pela fé e obras. Charles Metcalf opôs-se a ele diretamente, e declarou a simples verdade do evangelho. (...). Entretanto, o sr. Washington e Watson, estavam indo a todas as partes e confirmando a descrença. (...). Às quatro horas, nós os encontramos (sem pretendermos), e nos opusemos a eles novamente. (...). Mas o sr. Washington foi até lá, antes de mim, e havia começado a ler o Bispo Ball, contra o Testemunho do Espírito. Ele me disse que foi autorizado pelo ministro da paróquia a assim proceder. Eu aconselhei a todos que valorizavam suas almas a irem embora; (...). No meio da disputa, a esposa de James Mear começou a sentir dores. Eu orei com ela um pouco, quando o sr. Washington foi embora; (...). Com muita dificuldade, a levamos para a casa da sra. Shrieve (onde também o sr. Washington tinha estado antes de nós); (...). Mas o inimigo estava muito vigilante. Quase tão logo saímos da cidade, o ministro mandou aviso, ou foi a cada um dos membros, e, tendo discutido e ameaçado, confundiram-nos extremamente, de modo que eles todos se dispersaram amplamente. (WESLEY, 2005, p. 173-175)

Em outra carta privada, por exemplo, de 9 de agosto de 1740, John Wesley enuncia estar dividido em termos de ideias e em relação ao posicionamento metodista para com seu amigo Whitefield, afirmando que ambos, nesse momento, tinham opiniões divergentes a respeito da prática metodista. Eis o excerto desta carta privada:
Existem fanáticos, ambos pela predestinação, e contra ela. Deus envia uma mensagem para aqueles de ambos os lados. Mas ninguém a receberá, exceto de alguém de sua própria opinião. Portanto, por um tempo, você é forçado a ser de uma opinião, e eu de outra. (WESLEY, 2005, p. 139)

John Wesley, em outra carta privada, de 14 de maio de 1738, para o Reverendo William Law, também enuncia que se sentia desprezado pelo seu antigo formador, chegando a questioná-lo sobre sua própria fé e seus conhecimentos sobre o Evangelho de Cristo:

Se você é nascido de Deus, você aprovará o objetivo, embora possa ser fracamente executado. Se não, eu me angustiarei por você, não por mim mesmo. Porque, como eu não busco o louvor de homens, nem me preocupo com o desprezo quer seu ou algum outro. (...). Agora, senhor, permita-me perguntar, como você responderá ao nosso Senhor, em comum, que você nunca me deu este conselho? Você nunca leu os Atos dos Apóstolos, ou a resposta de Paulo àquele que disse: "o que devo fazer para ser salvo?". Ou você é mais sábio do que ele? Por que eu dificilmente ouvi você dizer o nome de Cristo? (WESLEY, 2005, p. 143-144)

0 autor inglês enuncia, em outra carta privada, que é também incompreendido pelos próprios cristãos, de um modo geral, sejam anglicanos, católicos ou morávios. John Wesley, assim, no processo produtivo e enunciativo da carta privada a seguir, por exemplo, apresenta também sua paratopia, seu caráter insustentável em relação ao espaço religioso onde busca sua inscrição. É por meio da enunciação das cartas que o autor cria o mundo ao qual apresenta sua condição paratópica, ou seja, é através da prática discursiva da troca de cartas e de seu próprio processo produtivo que Wesley expõe as oposições, conflitos e incompreen- 
sões sofridas frente à comunidade religiosa. Em outras palavras, Wesley manifesta, no processo produtivo de suas cartas privadas, a sua impossível e difícil negociação em se inscrever entre o espaço religioso e a sociedade que o circunscrevem, a sua paratopia, a condição e o produto, ao mesmo tempo, dessas cartas. Na carta privada de 7 de julho de 1738, ele enuncia o seguinte:

Entristeço-me ao pensar como o santo nome pelo qual somos chamados seja blasfemado entre os pagãos porque veem cristãos descontentes, cristãos irascíveis, cristãos ressentidos, cristãos mundanos, sim, (...), enquanto veem cristãos julgando uns aos outros, ridicularizando uns aos outros, falando mal uns dos outros, aumentando em vez de carregarem as cargas uns dos outros. (WESLEY, 1991, p. 19)

A construção das cenografias possíveis das cartas privadas de John Wesley, por sua vez, se apresenta, na sua grande maioria, como exógena, em que se distancia da rotina genérica do gênero do discurso ao qual está mobilizado (c.f. MAINGUENEAU, 2008b). Nessa perspectiva, observamos que suas cartas privadas encenam uma pregação, uma evangelização, para além de uma carta íntima. As cartas privadas de John Wesley encenam um evangelizador pregando para seus fiéis no interior de um púlpito, ou uma paróquia no interior de uma igreja.

Desse modo, todas as cenografias construídas nas e pelas cartas privadas de Wesley legitimam e constituem seu processo enunciativo, sua prática discursiva e, consequentemente, seus enunciados, assim como todos estes fatores também legitimam e constituem as cenografias construídas, pois é através das encenações de pregação e evangelização que Wesley busca forjar sua identidade criadora (seu estatuto de autor/ evangelizador) e legitimar suas produções do espaço canônico e associado no interior do campo religioso inglês do século XVIII.

Eis alguns excertos de cartas privadas de John Wesley, como exemplos, que evidenciam o funcionamento das cenografias supracitadas. São cartas privadas, respectivamente, de $1^{\text {o }}$ de julho de 1768, de 19 de outubro de 1772, de 11 de março de 1788, de 28 de outubro de 1754 e de 15 de junho de 1771:

Mas Ele, que é por você, é maior que todos os que estão contra, apenas tenha cuidado com os maus raciocínios! (...). O pecado propriamente dito não é mais nem menos do que "uma transgressão voluntária de uma conhecida lei de Deus". (...). Cuidado com o orgulho! Cuidado com aduladores! Cuidado com o desânimo! Mas acima de tudo, cuidado com a afeição desordenada! (...). 0 senhor é apenas um mordomo do que o Senhor lhe confiou, para ser disposto não de acordo com a sua vontade, mas com a dEle. (...). Ele está com você no fogo de modo que as chamas não arderão em você. (...). Felizes são aqueles que fazem a Sua vontade, e mais felizes ainda aqueles que a experimentam. (WESLEY, 1991, p. 18, 20, 25, 28 e 41)

\section{Considerações finais}

A partir das análises apresentadas neste artigo, é possível sustentar que as cartas privadas de John Wesley (enquanto cena genérica e produção do espaço associado desse autor) funcionam como um embreante paratópico. A troca de cartas privadas engendradas pelo autor ancora uma prática discursiva que busca legitimar e constituir seu posicionamento metodista, sua identidade criadora enquanto autor e evangelista do discurso religioso e suas produções, sejam as do espaço canônico (inclinado na bíblia e nas suas pregações), sejam as do espaço associado (suas cartas privadas propriamente, seu diário etc.) no interior do campo 
religioso inglês do século XVIII. Desse modo, é possível perceber, na troca de cartas privadas, o texto como forma de gestão do seu contexto.

Com a análise da constituição da paratopia, em especial, percebemos que as cartas privadas de John Wesley só existem e só puderam ser produzidas a partir de condições de produções específicas que necessitam sempre de uma relação e uma negociação (difícil) do autor com o espaço religioso e com a sociedade nos quais ele pretende se inscrever. É, pois, também por meio dessas cartas privadas que John Wesley gere sua paratopia.

Essas cartas privadas funcionam, assim, como embreantes paratópicos, pois estão para além da ideia de carta íntima. Essas cartas privadas de John Wesley funcionam como um embreante paratópico na medida que instauram um posicionamento e gerem a relação entre os integrantes da comunidade discursiva religiosa metodista. Nesse sentido, tais cartas privadas não se restringem, exclusivamente, a suas rotinas genéricas, pois, ao mesmo tempo em que John Wesley fala de si, ele fala também do seu posicionamento discursivo.

Portanto, se essas cartas privadas de John Wesley fossem apenas do tipo pessoal, um gênero próximo do conversacional, não poderíamos analisá-las pela perspectiva do funcionamento da autoria, pois haveria apenas a instância da pessoa. Essas cartas privadas são trocadas por um autor consagrado do campo religioso inglês (fundador de uma nova sociedade/igreja cristã) e, sendo assim, instituem um posicionamento específico no interior do campo discursivo. Essas cartas privadas podem ser tratadas, assim, enquanto um gênero do discurso institucionalizado (uma cena genérica) e enquanto uma produção do espaço associado de John
Wesley, em que se pode perceber: i) a manifestação das três instâncias constitutivas do funcionamento da autoria: a pessoa, o escritor e o inscritor; ii) a emergência da constituição da paratopia do autor em questão; e iii) as cenografias construídas nas e pelas cartas privadas.

\section{Referências}

BELLA, Izilda. Primeira década de cartas do Ver. John Wesley: Desde a Universidade de Oxford e Colônia Americana, até 1750. Copyright: eBook Kindle Amazon, 2018.

GENETTE, G. Seuils. Paris: Seuil, 1987.

GREEN, Richard. John Wesley, o evangelista. Trad. Izilda Bella. Vila Isabel: site da Igreja Metodista de Vila Isabel, 2005. Disponível em: $<$ http://www.metodistavilaisabel.org.br> Acesso em: 2 fev. 2020.

GREIMAS, A. J., COURTÉS, J. Sémiotique: dictionnaire raisonné de la théorie du langage. Paris: Hachette, 1979. v.l.

MAINGUENEAU, Dominique. Gênese dos discursos. São Paulo: Parábola Editorial, 2008a.

MAINGUENEAU, Dominique. Discurso literário. $2^{a}$ ed. São Paulo: Contexto, 2012.

MAIngueneaU, Dominique. Cenas de enunciação. Orgs. Maria Cecília Pérez de Souza-e-Silva e Sírio Possenti. São Paulo: Parábola Editorial, 2008b.

MAINGUENEAU, Dominique. Discurso e análise do discurso. Trad. Sírio Possenti. São Paulo: Parábola Editorial, 2015.

POTTS, J. M. Seleção das cartas de João Wesley. Trad. Cleide Zerlotti Wolff. São Bernardo do Campo: Imprensa Metodista, 1991.

RATTEMBURY, J. E. Wesley's Legacy to the World. London: The Epworth Press, 1928.

SOUSA JÚNIOR, Manuel José Veronez de. A carta privada de autores consagrados do campo literário: uma abordagem da cena genérica como embreante paratópico. 2018. Tese (Doutorado em Estudos Linguísticos) Instituto de Letras e Linguística - Programa de Pós-Graduação em Estudos Linguísticos, 
Universidade Federal de Uberlândia, Minas Gerais.

TELFORD, John. The letters of John Wesley. London: Epworth Press, 1931. Disponível em:< http://wesley.nnu.edu/john-wesley/the- letters-of-john-wesley> Acesso em: 2 fev. 2020. VERONEZ, Manuel. A cena genérica como embreante paratópico: contribuições epistemológicas para a Análise do Discurso. Polifonia: Estudos da Linguagem. v. 26, n. 43. Cuiabá, 2019.

Recebido em: 14/05/2020

Aceito em: 19/06/2020

Esta obra está licenciada com uma Licença Creative Commons Atribuição 4.0 Internacional. 